\title{
A new and easternmost species of Loureedia (Aranei: Eresidae) from Iran
}

\section{Новый и самый восточный вид рода Loureedia (Aranei: Eresidae) из Ирана}

\author{
Alireza Zamani', Yuri M. Marusilk ${ }^{2,3}$ \\ А. Замани, Ю.М. Марусик

\footnotetext{
${ }^{1}$ Zoological Museum, Biodiversity Unit, University of Turku, FI-20014, Finland. E-mail: zamani.alireza5@gmail.com

${ }^{2}$ Institute for Biological Problems of the North RAS, Portovaya Str.18, Magadan, Russia. E-mail: yurmar@mail.ru

${ }_{3}^{3}$ Department of Zoology \& Entomology, University of the Free State, Bloemfontein 9300, South Africa.

${ }^{2}$ Институт биологических проблем Севера ДВО РАН, Портовая 18, Магадан 685000 Россия.
}

KEY WORDS: Araneae, Middle East, velvet spiders.

КЛЮЧЕВЫЕ СЛОВА: Araneae, Ближний Восток, пауки-эрезиды.

ABSTRACT: A new species, Loureedia phoenixi sp.n., is described and illustrated on the basis of two male specimens from Alborz Province of Iran and its distribution is mapped based on the type locality and photographic records. These records represent the easternmost distribution limit of the genus.

How to cite this article: Zamani A., Marusik Yu.M. 2020. A new and easternmost species of Loureedia (Aranei: Eresidae) from Iran // Arthropoda Selecta. Vol.29. No.2. P.239-243. doi: 10.15298/arthsel. 29.2.09

РЕЗЮМЕ. Описан новый Loureedia phoenixi sp.n. на основе двух самцов из провинции Альборз. Показано его распространение: типовое местообитание и локалитеты задокументированные по фотографиям. Новый вид существенно расширяет ареал рода на восток.

\section{Introduction}

Loureedia Miller, Griswold, Scharff, Řezáč, Szüts et Marhabaie, 2012 is a recently described genus with three named species distributed in the Mediterranean, from Morocco and Spain to Israel [WSC, 2020], all of which have been surveyed by Henriques et al. [2018]. The genus is known from Iran based on unpublished material and photographic records [Szüts et al., 2018; Henriques et al., 2018]. We recently acquired two male specimens of Loureedia from northern Iran. Examination of the male palp and comparison of the abdominal pattern with those of other known species revealed it to be an undescribed species. Until recently, only three other species of Eresidae were known to occur in Iran: one species of Eresus Walckenaer, 1805 and two species of Stegodyphus Simon, 1873 [Zamani et al., 2020]. The goal of this paper is to provide a description of the new species and to compare the conductor morphology of all species of the genus.

\section{Material and methods}

The holotype was photographed at the Zoological Museum of the University of Turku, Finland, using an Olympus Camedia E-520 camera attached to an Olympus SZX16 stereomicroscope. Digital images were stacked using Zerene Stacker v 1.04. Length of leg and palp segments were measured on the dorsal side and are listed as: total length (femur, patella, tibia, metatarsus, tarsus). All measurements are given in millimetres. The type specimens will be deposited at the Muséum d'histoire naturelle, Genève, Switzerland (MHNG).

Abbreviations: Eyes: $A L E$ - anterior lateral eye, $A M E$ - anterior median eye, PLE - posterior lateral eye, $P M E$ - posterior median eye. Legs: $\mathrm{Fe}$ - femur, $\mathrm{Pt}$ patella, $T i$ - tibia, $M t$ - metatarsus, $T a$ - tarsus.

\section{Taxonomy}

\section{Family Eresidae C.L. Koch, 1845}

Genus Loureedia Miller, Griswold, Scharff, Řezáč, Szüts et Marhabaie, 2012

Loureedia Miller et al., 2012: 81.

Loureedia: Henriques et al., 2018: 5.

TYPE SPECIES. Eresus annulipes Lucas, 1857, Patria ignota [unknown site]

DIAGNOSIS. Males of Loureedia differ from those belonging to other genera by the strongly divergent branched conductor, with the branches subequal to the conductor's stem length ( $v s$. only the tip is branched or not branched). Females of Loureedia cannot be distinguished from those of Eresus.

COMPOSITION. Four species: L. annulipes (Lucas, 1857), L. colleni Henriques, Miñano et Pérez-Zarcos, 2018, L. lucasi (Simon, 1873) and L. phoenixi sp.n. 

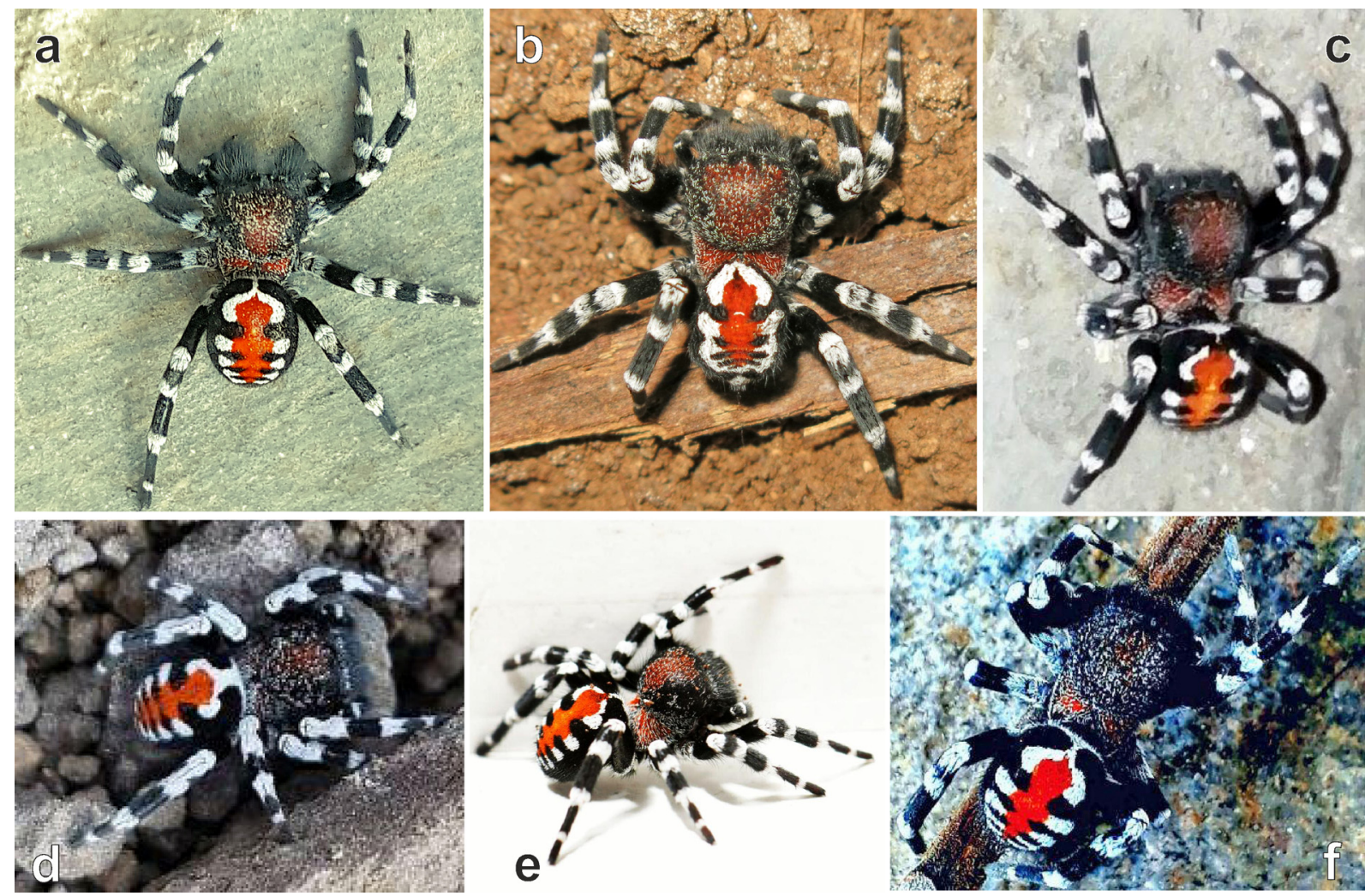

Fig. 1. Habitus of in vivo specimens of Loureedia phoenixi sp.n. Alborz Province: Karaj (N. Sheikh) (a), Tehran Province: Pardisan Park (A. Zamani) (b), Fars Province: Shiraz (Sh. Hesami) (c), Tehran Province: Kuhsar (B. Golavi) (d), Tehran Province: Rudehen (A. Bolhari) (e) and Kerman Province: Shahr-e Babak (H. Asgari) (f).

Рис. 1. Внешний вид in vivo самцов Loureedia phoenixi sp.n. Провинция Альборз: Каraj (фото N. Sheikh) (a); провинция Тегеран: Pardisan Park (фото A. Zamani) (b), провинция Фарс: Шираз (фото Sh. Неsami) (c), провинция Тегеран: Киһsar (фото B. Golavi) (d), провинция Тегеран: Rudehen (фото A. Bolhari) (е) и провинция Керман: Shahr-e Babak (фото H. Asgari) (f).

DISTRIBUTION. From Morocco and Spain to Iran.

Loureedia phoenixi sp.n.

urn:lsid:zoobank.org:act:

E3D2652B-2ED2-4C42-941F-AEBE91267524

Figs $1 \mathrm{a}-\mathrm{f}, 2 \mathrm{a}-\mathrm{d}, 3 \mathrm{a}-\mathrm{f}, 4$.

Loureedia sp.: Henriques et al., 2018: 7, fig. 2h $\left(\sigma^{7}\right)$

TYPE MATERIAL. Holotype $\sigma^{7}$, paratype $1 \sigma^{7}$ (MHNG): IRAN, Alborz Province: Karaj, Chenarak, $35.8845821^{\circ} \mathrm{N}, 50$. $9306001^{\circ} \mathrm{E}, 8.11 .2019$ (A. Beigi).

PHOTOGRAPHIC RECORDS. $1 \sigma^{7}$ : Alborz Province: Karaj, 11.10.2016 (N. Sheikh); $10^{7}$ : Fars Province: Shiraz, Shahrak-e Sadra, $29.8047439^{\circ} \mathrm{N}, 52.4232364^{\circ} \mathrm{E}, 02.11 .2018$ (Sh. Hesami); 1 $\square{ }^{7}$ : Kerman Province: Shahr-e Babak, Meymand Vil., 30. $229139^{\circ} \mathrm{N}, 55.3718125^{\circ} \mathrm{E}, 27.10 .2017$ (H. Asgari); $1 \mathrm{O}^{7}$ : Tehran Province: Kuhsar, $35.7744789^{\circ} \mathrm{N}, 51.293026311^{\circ} \mathrm{E}, 11.11 .2018$ (B. Golavi); $1 \mathrm{O}^{\top}$ : Pardisan Park, $35.7451381^{\circ} \mathrm{N}, 51.3558087^{\circ} \mathrm{E}$ 5.11.2016 (A. Zamani); $10^{7}$ : Rudehen, 10.2015 (A. Bolhari).

ETYMOLOGY. The new species is named after the American actor, producer and animal rights activist Joaquin Phoenix in recognition of his praised portrayal of the title character in the 2019 movie "Joker" and as a reference to the male abdominal pattern of the new species, which resembles the famous facial makeup of this character.

DIAGNOSIS. The new species differs from congeners by the prolateral arm of the conductor $(P a)$ which is pointed and almost the same length as the retrolateral arm of the conductor $(R a)$. The conductor arms are not as pointed and retrolateral arm is distinctly longer than the prolateral one in other species (cf. Figs $3 \mathrm{f}$ and $3 \mathrm{~g}-\mathrm{i}$ ).

DESCRIPTION. Male (holotype). Habitus as in Figs 1a-f, 2a-d. Total length 8.35. Carapace 5.25 long, 4.0 wide. Eye sizes and interdistances: AME: 0.14, ALE: 0.26, PME: 0.29, PLE: 0.19, AME-AME: 0.2, ALE-AME: 0.11. Carapace, sternum, labium, chelicerae and maxillae dark brown with tones of red. Carapace mostly covered by long black setae and scattered short white setae, with localized patches of short red setae mostly in the pars thoracica or the center of pars cephalica. Legs covered with thin black hairs, with distinct regions of white hairs at the joints of all segments that rarely connect with each other, forming distinct white rings. Abdomen with a compact, longitudinal median red stripe with lateral projections with compact white spots at their tips. The anteriormost pair of white spots either contiguous or very close to each other, sometimes merging with a distinct white spot above the pedicel, forming an anterior white shield.

Legs and palp measurements:

\begin{tabular}{|l|c|c|c|c|c|c|}
\hline & Fe & Pt & Ti & Mt & Ta & Total \\
\hline Palp & 1.58 & 0.75 & 0.25 & - & 1.2 & 3.78 \\
\hline I & 3.25 & 1.5 & 1.88 & 2.13 & 1.38 & 10.14 \\
\hline II & 2.88 & 1.5 & 1.51 & 1.88 & 1.13 & 8.9 \\
\hline III & 2.75 & 1.5 & 1.38 & 1.63 & 0.95 & 8.21 \\
\hline IV & 3.5 & 1.75 & 2.25 & 2.25 & 1.25 & 11 \\
\hline
\end{tabular}



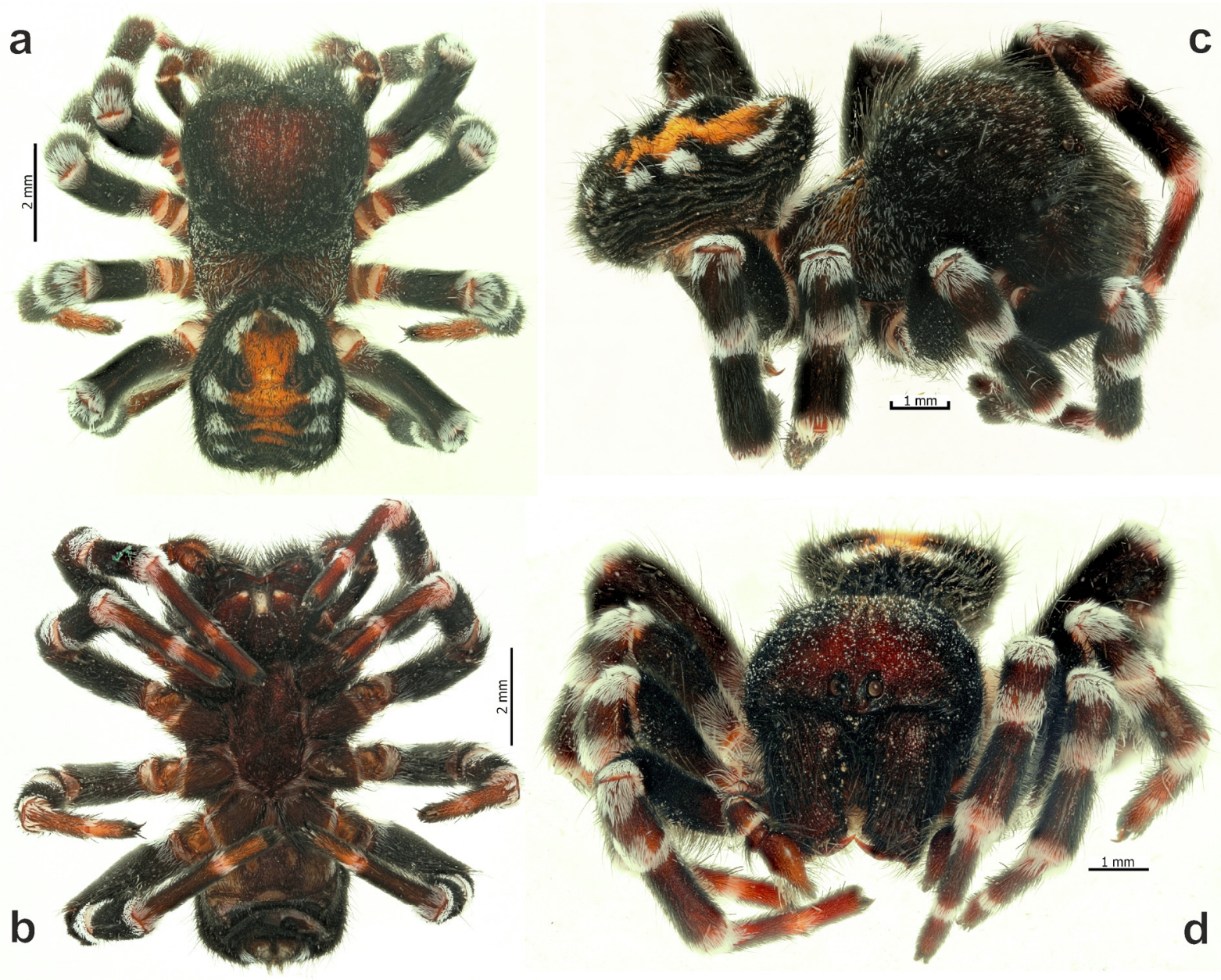

C

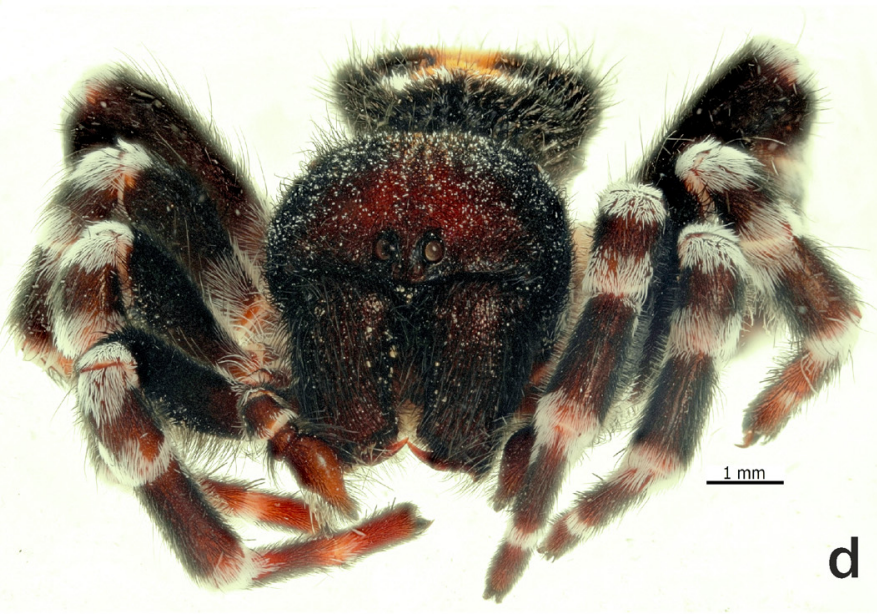

Fig. 2. Habitus of the holotype of Loureedia phoenixi sp.n.: a - dorsal, b - ventral, c - lateral, d - frontal.

Рис. 2. Внешний вид голотипа Loureedia phoenixi sp.n.: a - сверху; b - снизу; с - сбоку; d - спереди.

Palp as in Figs 3a-f. Femur as long as tibia+cymbium, 3 times longer than wide. Length of conductor's arms subequal. Tibia shorter than wide. Cymbium about 2 times longer than wide. Prolateral margin of conductor almost straight, forming right angle with the posterior margin. Prolateral and retrolateral arms of conductor subequal in length, both with sharply pointed tips.

Female. Unknown.

PHENOLOGY. All available records of the new species are from late October and early November, congruent with the known phenology of most other Loureedia species [Henriques et al., 2018].

DISTRIBUTION. The new species is the first of the genus to be found outside of the Mediterranean, and this extends the distribution over $1500 \mathrm{~km}$ to the east. It is endemic to Iran (Fig. 4), collected from the type locality in Alborz Province, with photographic records in Tehran, Fars and Kerman provinces, northern and south-central Iran. Although, specimens from the north and south appear identical, we cannot rule out that the southern populations (for which only photographic records are available) could represent a different species; this shall be further investigated when specimens from those localities are available.
Acknowledgments. We are grateful toward Amir Beigi (Karaj, Iran) for providing us with the collected material, and Hadis Asgari (Kerman, Iran), Amir Hossein Bolhari (Tehran, Iran), Bayan Golavi (Tehran, Iran), Shahram Hesami (Shiraz, Iran) and Niloofar Sheikh (Karaj, Iran) for providing us with photographic records. We thank two anonymous reviewers and editor Kirill G. Mikhailov for helpful comments and suggestions. The English of the earlier draft was kindly checked by Sarah Crews (California, US).

\section{References}

Henriques S., Miñano J., Pérez-Zarcos L., Řezáč M., Rodríguez F., Tamajón R., Martínez-Avilés J. 2018. First records of Loureedia (Araneae, Eresidae) from Europe, with the description of a new species and a survey of the genus // Revista Ibérica de Aracnología. Vol.33. P.3-20.

Miller J. A., Griswold C.E., Scharff N., Řezáč M., Szüts T., Marhabaie M. 2012. The velvet spiders: an atlas of the Eresidae (Arachnida, Araneae) // ZooKeys. Vol.195. P.1-144.

Szüts T., Kaya R.S., Ya mur E.A., Oger P., Fabregat M., Moradi M., Miller J.A. 2018. East side story: review of the Loureedia species (Eresidae). Abstract book of the 31st European Congress of Arachnology, 8-13 July 2018, Vác, Hungary, P.133. 


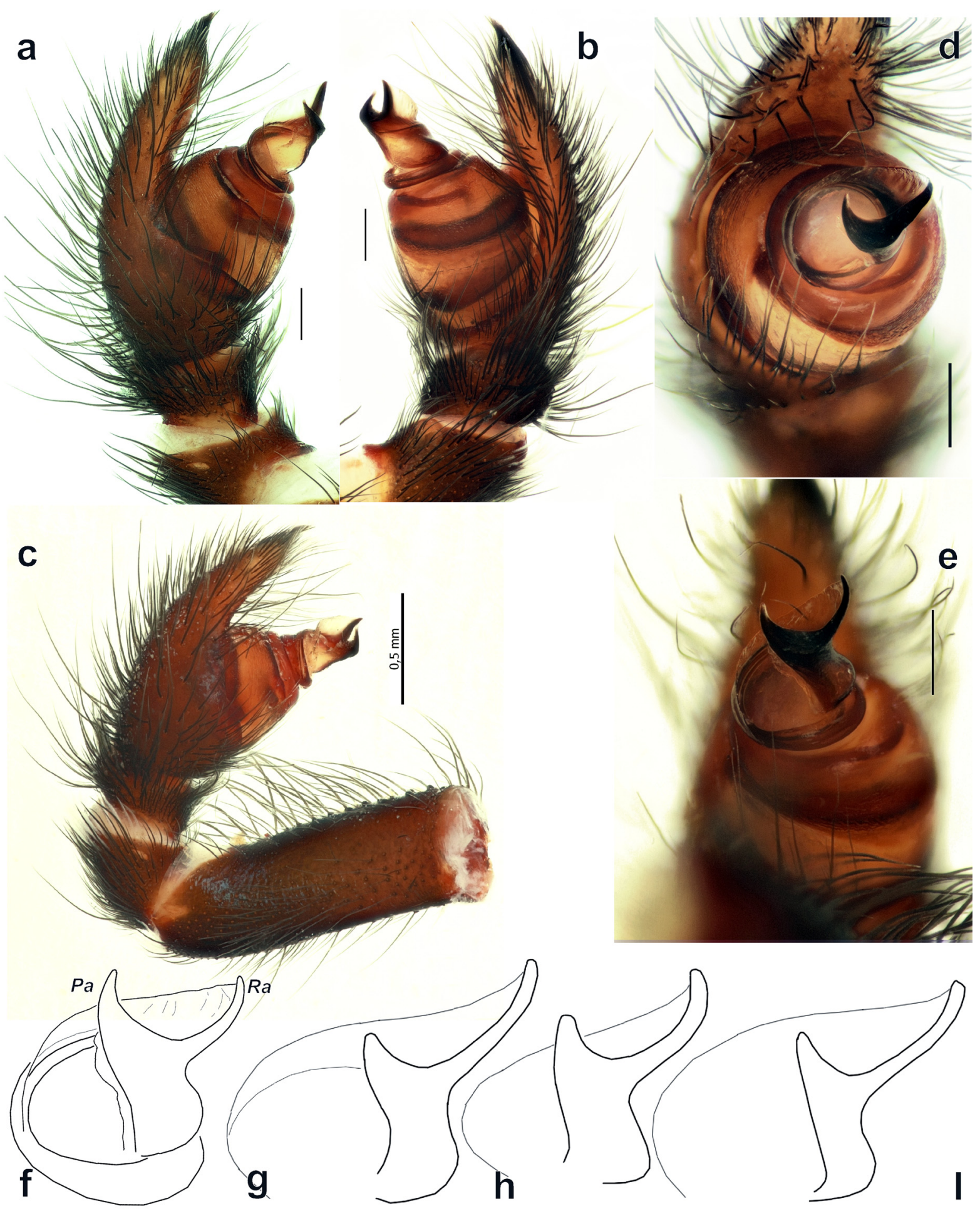

Fig. 3. Male palps of Loureedia phoenixi sp.n. (a-f, holotype), L. annulipes (g), L. lucasi (h) and L. colleni (i). a, c - prolateral, $\mathrm{b}-$ retrolateral, d - apical, e- $\mathrm{i}$ - ventral, $\mathrm{f}-\mathrm{i}$ - conductor, ventral. $\mathrm{g}-\mathrm{i}$ - after Henriques et al. [2018] with modifications. Scale $=0.02 \mathrm{~mm}$ if not otherwise indicated. Abbreviations: $P a$ - prolateral arm of conductor, $R a$ - retrolateral arm of conductor.

Рис. 3. Пальпа самца Loureedia phoenixi sp.n. (голотип, a-f), L. annulipes (g), L. lucasi (h) and L. colleni (i). a, c — пролатерально; $\mathrm{b}$ - ретролатерально; d - сверху, е-i - снизу, f-i - кондуктор снизу. g-i - по Henriques et al. [2018] с изменениями. Масштаб 0,2 мм если не указано иначе. Сокращения: $P a$ - пролатеральная ветвь кондуктора, $R a$ - ретролатеральная ветвь кондуктора. 


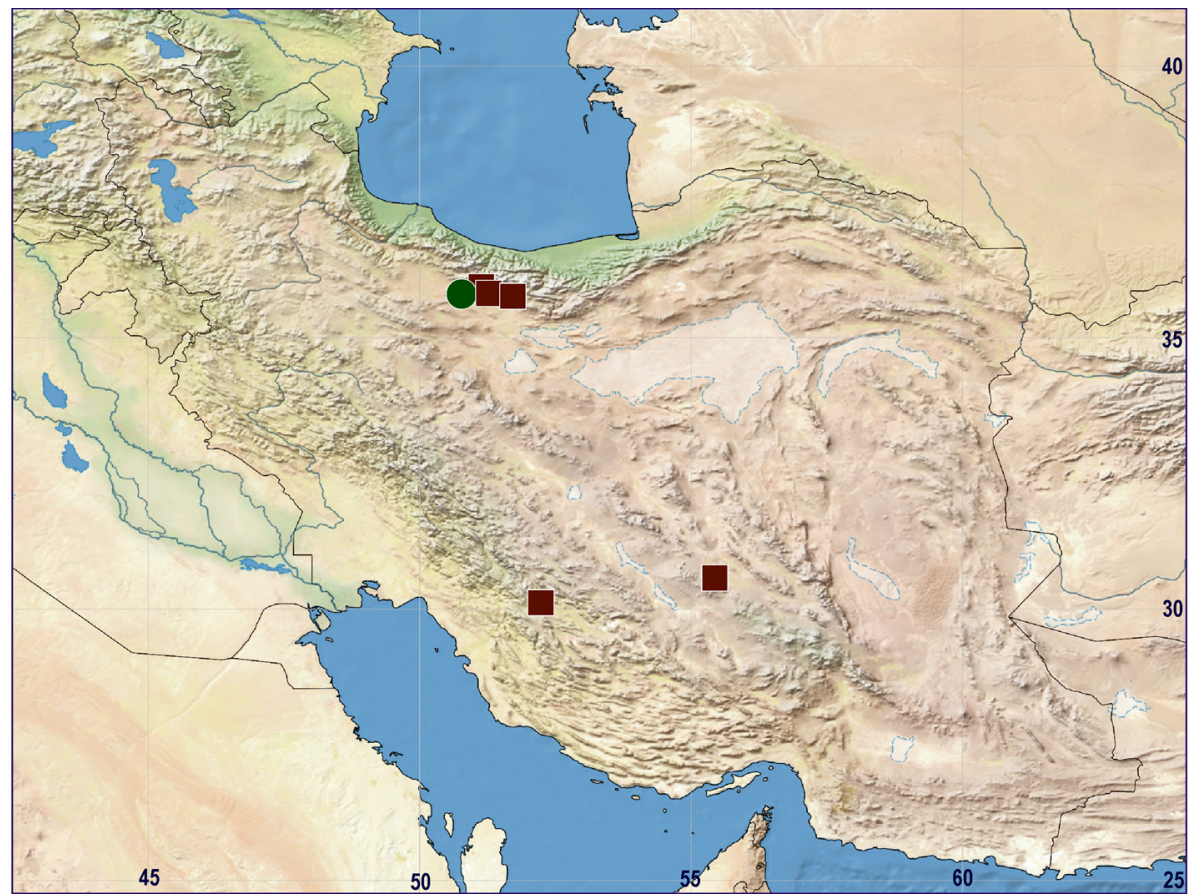

Fig. 4. Distribution of Loureedia phoenixi sp.n. in Iran. Circle - type locality, squares — photographic records.

Рис.4. Распространение Loureedia phoenixi sp.n.. Круг — типовой локалитет; квадраты — места, где задокументированы находки по фотографиям.

WSC. 2020. World Spider Catalog. Version 21.0. Natural History Museum Bern, online at http://wsc.nmbe.ch, accessed on 27.04.2020.

Zamani A., Mirshamsi O., Marusik Y.M., Moradmand M. 2020. The Checklist of the Spiders of Iran. Version 2020, Online at http://www.spiders.ir 